\title{
INFLUENCE ANALYSIS OF NON PERFORMING FINANCING BY PROFIT-LOSS SHARING FINANCING CONTRACT TO THE PROFITABILITY OF ISLAMIC COMMERCIAL BANK IN INDONESIA
}

\author{
Taudlikhul Afkar \\ Accounting Department, Faculty of Economics \\ Universitas PGRI Adi Buana \\ afkar@unipasby.ac.id
}

Received: 16-03-2018

Revisied: 25-04-2018

Accepted: 10-09-2018

\section{ABSTRACT}

This study aims to analyze the effect of non performing financing (NPF) from financing for the results of Mudaraba and Musharaka contracts on the profitability of sharia commercial banks in Indonesia. To achieve these objectives statistical tests were performed using multiple linear regression because there are two predictor variables and one dependent variable. Sampling technique use by saturated because there are only 13 sharia commercial banks in Indonesia until now. The unit of analysis used the time series data type of processing over the last three years conducted by the Financial Services Authority (OJK). The results of this study indicate inconsistency with the theory that non-performing financing (NPF) measured from Mudharabah and Musyarakah contracts has insignificant effect on the profitability of Sharia Commercial Banks in Indonesia, but this is consistent with the characteristics of people in Indonesia who tend to be consumptive rather than productive.

Keywords: Financing; Mudaraba Financing; Musharaka Financing; Non-Performing; Profit-Loss; Profitability; Sharing Financing.

How to cite: Afkar, T. (2018). Influence Analysis of Non Performing Financing by Profit-Loss Sharing Financing Contract to The Profitability of Islamic Commercial Bank In Indonesia. Akrual: Jurnal Akuntansi. 10 (1): 1-14. DOI: http://dx.doi.org/10.26740/jaj.v10n1.p1-14

\section{INTRODUCTION}

Islamic banks are financial institutions that concentrate on the real sector than the financial sector (Afkar, 2015a). The real sector is the main target for Islamic banks in performing their role as intermediary institutions (Afkar, 2015b) as an intermediary institution, it more channeling funds through financing in the real sector with the aim to provide convenience for small and medium entrepreneurs to strengthen the economy nationally. It better known as banks with profit-sharing schemes (Karim, 2010). In doing financial activities should be in a stable condition and done efficiently (Thorsten,
Beck; Asli, Demirguc-Kunt \& Ourda, 2013) and the financial ratios of Islamic banks show good quality (Oktaviana, 2012) shown during the financial crisis of the 2007-2008 period Islamic banks were seen stronger in terms of credit.

Financing disbursed by Islamic banks in the real sector more than in financing the financial sector, because Islamic banks more manage their capital with the principle of prudence (Afkar, 2017c). In channeling the financing of the cattle must pay attention to the level of liquidity (Diallo, Fitrijanti, \& Tanzil, 2015) Islamic bank financing is done with various schemes of the contract as needed. 
Profitability is one of the components that must be maintained by Islamic banks for business continuity, in this case of course can not be separated from the risk of financing the problematic financing or non-performing financing (NPF). The financial performance of financial institutions such as banks must be well guarded so as not to create an element of accounting fraud (Afkar, 2016).

In order to maintain the continuity of its business, the bank must manage credit risk from its financing (credit risk) at an adequate level so as to minimize the potential loss from financing. Recording should also be done well in financial administration (Afkar, 2015d). Risk management of the financing is done, among others, by always maintaining the quality of the financing in the form of quality asset maintained and the determination of allowance for the elimination of adequate assets. With good risk management as reflected by the asset quality and availability of adequate allowance for losses, banks are expected to increase their role in performing the banking intermediation function (Bank Indonesia, 2007a). There is a need for good regulatory arrangements to anticipate losses arising from the write-off of bad debts (Afkar, 2016b).

Financing in Islamic banks in general can be seen from the types of working capital financing, investment financing, and consumer financing (Afkar, 2014a). The financing provided positively affects economic growth in the real sector (Hasyim, 2016). In addition, financing is also divided into different contracts, generally financing by Islamic banks such as Mudaraba, Musharaka, Murabaha, Salam, Istishna', Ijarah and Qardh. Other financing becomes a complementary scheme scheme to meet the needs of customers such as Wadiah, Rahn, Sharf, and so on (Afkar, 2015b).

Profit-Loss Financing in Islamic Banks can be done by way of Mudaraba and Musharaka (Nurhayati and Wasilah, 2015; Karim, 2010), the contract is a type of sharia contract in financing that is destined to gain profit. Profit-Loss Sharing is also a strategy of Islamic banks in developing their business (Afkar, 2011). Mudaraba is a financing given to a customer or fund manager (Mudarib) of $100 \%$ of the owner of the fund (Sahibul Maal) with a profit-sharing agreement. Musharaka is a financing in the form of cooperation, where both parties pay their respective capital with the profit sharing agreement (Nurhayati and Wasilah, 2015). (Blanchflower, 1991) study in the United Kingdom shows that the profitsharing system is a good but statistically insignificant system of productivity.

Each financing has an unaccountable risk or the rate of return of the customer does not match expectations, in other words there is bad credit(Afkar, 2014, 2017a). Research by (Afkar, 2014b) shows that credit risk affects the adequacy of capital, thus impacting the more careful management of assets. The results of the research (Permata, Yaningwati, \& A, 2014) show that Mudaraba financing has a significant negative effect on profit change, as well (Anjani \& Hasmarani, 2015) Mudaraba financing has a negative and significant effect on profitability, this negative 
effect is due to the risk of Mudaraba the loss will have an impact on the rate of return on capital. This is different from the results of research (Wibowo \& Sunarto, 2014) Mudaraba financing has a positive effect on profitability.

Saputra's research (Saputra, 2013) states that the partial non-performing financing (NPF) of financing Mudaraba and nonperforming financing (NPF) of Musharaka financing does not significantly affect the profitability of Islamic banks, while simultaneously significant effect. As one of the efforts to minimize the potential losses caused by Non-performing Financing, Islamic Comercial Banks and Islamic Business Units can perform Financing Restructuring to customers who experience a decrease in payment ability and still have good business prospect and able to fulfill their obligation after restructuring (Bank Indonesia, 2008). In addition, if not paid attention to business financial liquidity will also occur when there are problem loans (Afkar, 2014), although liquidity is not affected by profitability (Afkar, 2017d). Business finance needs to be managed well in order to avoid significant problems (Uman and Afkar, 2011).

Some studies show differences in results, where some research shows that nonperforming financing does not affect to profitability. This research would like to provide a more specific study by separating profit-sharing categories in comprehensive financing from banks and financing by cooperation schemes. Where both types of financing are financing that are unproviding certainty of profit in running their business. This is the problem that mudharabah financing and musyakah financing do not include receivables but are purely a percentage-sharing system. Meanwhile the characteristics of the people in Indonesia tend to be consumptive rather than productive, so that it is interesting to do research on financing this profit-sharing.

\section{LITERATURE REVIEW}

\section{Profit-Loss Sharing Principle}

Profit-Loss Sharing is a characteristic of Islamic banking products and the basis for Islamic bank operations as a whole. ProfitLoss Sharing is based on the principle of almudaraba, in which case Islamic banks will act as partners between people who have excess funds and people who lack funds, with savers. Innovation of new Islamic product approach is needed in bridging financial institutions with customers (Laldin \& Furqani, 2016).

Profit-Loss Sharing System is a system that encompasses the procedure for the distribution of business results between the fund owner and the fund manager, Profit-Loss Sharing principle uses the Mudaraba and Musharaka (Mumammad, 2008) contracts. Profit sharing is also a product of Islamic banks that have a pretty good role in the economy. Mentions that profit-loss sharing is a bonus based on profitability that is able to motivate someone to show strong performance (Fang, 2015).

The contract used in Islamic transactions seen from the presence or absence of compensation, in fiqih muamala there are 
two types of contract is Tabarru contract and Tijara contract. Tabarru contract is used for transactions that do not intend to make a profit or are helpful in the good. While Akad Tijarah is used for transactions related to profit (Nurhayati and Wasilah, 2015).

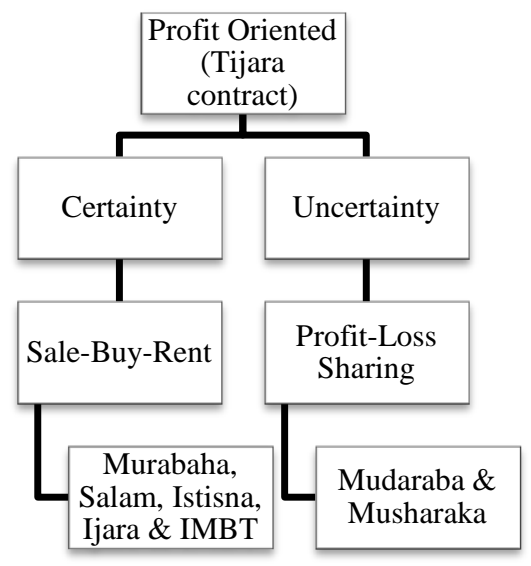

Figure 1. Tijara Contract

\section{Mudaraba Financing}

Mudaraba financing provided to fund managers (mudarib) which have a purpose for the management of a particular business, with the sharing of the proceeds or income earned (profit sharing) divided according to the ratio agreed by both parties (Usanti and Shomad, 2013).

Type of Mudaraba financing is : 1) Mudaraba Muqayyada is cooperation between sahib al-maal with mudarib, where mudarib is free to determine the place of business and type of business managed; 2) Mudaraba mutlaqa is mudarib can not determine the place and type of business being managed.

Mudaraba financing requirements are: 1) there is a provider of funds, 2) statement of consent (ijab) and deal (kabul) declared by the parties to indicate the wishes of each party that includes the supply and demand must explicitly indicate the purpose of contract, acceptance and offer is made when the contract and the contract is poured in writing, the presence of capital or funds recognized by the amount and type, the capital can not be in the form of receivables, the mudarib's profit is the amount earned as excess capital, proportional profit-loss sharing, and the fund provider bears all losses on the managed business (Usanti and Shomad, 2013 ).

\section{Musharaka Financing}

Musharaka financing is a financing done by the bank where the bank acts as the owner of the fund or participate as a business partner managed by other parties. Profit gained in accordance with how much capital invested that has been agreed at the beginning of the agreement. If the business fails, the loss will be borne together in proportion to equity (Rivai, 2010).

Kind of Musharaka financing in differentiation into two types namely: 1) Shirka amlak is the ownership of goods together on a goods without being preceded by a contract because of an inheritance, 2) Shirka uqud is union formed because the parties deliberately make agreements to cooperate (Usanti and Shomad, 2013).

Pillars and Musharaka financing conditions include: 1) statement of consent (ijab) and deal (kabul) declared by the parties to indicate their will in contract, 2) contracting parties must be competent in law, 3) there is an object of contract covering working capital, profit and loss. 


\section{Non-Performing Financing}

Islamic bank durability is one of them can be seen from the resilience of credit or financing provided by managing the financing problem below the threshold (Afkar, 2015a). Credit is the largest business activity undertaken by banks (Judisseno, 2005). Loans that are problematic is one form of risk that must be faced by financial institutions both banks and other financing institutions. The collectivity of banks in collecting back on financing or credit already given can be seen from the comparison between the returns received and the financing provided by the percentage of Non-Performing Loans for conventional banks and NonPerforming Financing for Islamic Banks (Judisseno, 2005). Non-performing loans are classified as substandard, doubtful, and stalled against all financing that has been issued (Juddiseno, 2005)

Bad Debt deals with the customer's ability to repay the loan. When the customer is completely unable to repay the loan with interest or nisbahnya then the receipt back from financing that has been given can be said to be jammed so that affect the bank's ability to manage finance. Non-performing loans (Bank Indonesia, 2009) are categorized as the collectibility of earning assets whose criteria are questionable or loss.

Bank Indonesia requires the elimination of non-performing loans to maintain the continuity and financial security of depositors (Bank Indonesia 2009). Numbers of problem financing can result in reserve funds for the elimination of problematic financing is also large resulting in decreased profitability of banks in general (Bank Indonesia, 2009). Measurement of bank profitability can be seen from Return On Assets (ROA) (Sutojo, 2008). The reserved cost will be greater when it is necessary to reserve for non-performing financing.

\section{Profitability}

Islamic banks use the type of tijarah agreement to conduct transactions in the profit-sharing system (Nurhayati and Wasilah, 2015). The profit sharing system used in syariah banks can be done by Mudaraba and Musharaka (Afkar, 2015b).

Profit is one of the elements that must be met in running a business with the type of profit oriented. Financial progress is usually measured by looking at the company's management capabilities in managing assets and capital to gain profit or profit. There is no profit-oriented company that does not prioritize profit in its business. Profit is an advantage gained from the difference in income by expenditure or expense.

Profitability is the ability of a business to earn profits related to its own sales, total assets, and equity, so that long-term investors will perform the required profitability analysis in a business (Saputra, 2013). (Satriawan \& Arifin, 2012), profitability ratios are the result of management policy to measure the size of the profits obtained by a company.

The ratios used to calculate the rating of capital factor, asset quality, earnings, liquidity and sensitivity to market risk are differentiated into main ratio, supporting ratio and observed ratio. The main ratio is the ratio that has a 
strong influence (high impact) on Bank Soundness, while the ratio of support is the ratio that directly affect the main ratio and observed ratio is the additional ratio used in the analysis and consideration (Bank Indonesia, 2007b).

Bank Indonesia Circular Letter number 3/30/DPNP dated December 14, 2001 explained that in measuring the level of profitability can be done by using Return On Asset (ROA) and Return On Equity (ROE). Measurement of profitability by using Return On Assets (ROA) is a measurement of profitability with assets owned, while profitability measurement by using Return On Equity (ROE) is a calculation with own equity.

In accordance with Bank Indonesia Circular Letter number 3/30 / DPNP dated December 14, 2001 then the measurement of profitability ratios by using Return On Assets (ROA) is as follows:

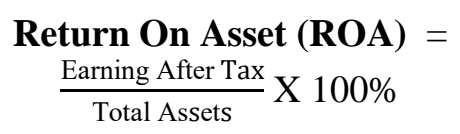

\section{Research Hypothesis}

Mudaraba, Musharaka, Murabaha, and Qardh schemes have an important role for Islamic banks in their profit-making efforts. Credit risk arising from non performing financing affects the capital of Islamic banks (Afkar, 2014). The endurance of Islamic banks in Indonesia is better than conventional banks because the credit risk experienced during the global financial crisis period is still below $5 \%$ and the level of profitability of Islamic banks is relatively safe (Afkar, 2015a). Uncollectible accounts receivable due to non performing financing may result in high operational costs that may affect the Islamic bank's profitability in Indonesia (Afkar, 2017a). Saputra's study shows that non-performing financing of Mudaraba financing negatively affects the profitability of Islamic banks (Saputra, 2013).

Hypothesis 1: Non-Performing Financing (NPF) Mudaraba Financing Influence to the Profitability of Islamic Commercial Bank

The ability of Islamic banks to earn profits is influenced by the financing provided through the financing of small and medium enterprises (SMEs) with Islamic schemes conducted for business activities (Afkar, 2017c). The profitability of Islamic banks is not influenced by Mudaraba financing but is influenced by qardh financing (Afkar, 2017b). Musharaka financing has a positive effect on profitability as measured by Return On Equity (ROE) (Permata et al., 2014). Saputra's research shows that non-performing financing of Musharaka financing negatively affects the profitability of Islamic banks (Saputra, 2013).

Hypothesis 2: Non-Performing Financing (NPF) Musharaka Financing Influence to the Profitability of Islamic Commercial Bank

Mudaraba Financing and Musharaka Financing simultaneously have a positive effect on profitability as measured by Return On Equity (ROE) (Permata et al., 2014). Mudaraba Financing and Musharaka Financing have a significant differentiation effect, Mudaraba financing has a significant but negative effect on profitability, while Musharaka financing has a significant positive effect on profitability (Anjani \& Hasmarani, 2015). Islamic bank credit risk can not be 
Afkar, Influence Analysis of Non Performing Financing...

separated from the financing that has been given to customers, the occurrence of bad loans because customers can not afford to pay the debt when the interest rate rises in the event of global financial crisis (Afkar, 2015a). Research (Saputra, 2013; Wibowo \& Sunarto, 2014)shows that non-performing financing (NPF) of Mudaraba Financing and NonPerforming Financing (NPF) Musharaka Financing simultaneously negatively affects Profitability of Islamic Bank.

Hypothesis 3: Simultaneously Non Performing Financing (NPF) Mudaraba Financing And Non-Performing Financing (NPF) Musharaka Financing Influence to the Profitability of Islamic Commercial Bank

\section{RESEARCH METHODS}

\section{Types of Research}

This study uses a quantitative approach with the aim to test data statistically using multiple linear regression because there are two predictor variables and one dependent variable. it uses secondary data from the performance report of Sharia Commercial Banks in Indonesia that is processed in accordance with the needs of research.

\section{Population and Sample}

The population in this study is the Sharia Commercial Banks in Indonesia as many as 13 Banks. Sampling used saturated sample technique, because number of population are small, so that used as many as 13 Sharia Commercial Banks. The data used are the financial statements of Sharia Commercial Banks in Indonesia in time series over the last 3 (three) years in order to provide more updated research results and the data has been delegated to the Financial Services Authority (OJK) from Bank Indonesia. The unit of analysis in this research is the calculation of Non Performing Financing (NPF) of Mudharabah Financing contract and Musyarakah Financing contract and profitability of Sharia Commercial Bank.

\section{Operational Variable}

Non-Performing Financing of Mudaraba Financing $\left(\mathbf{X}_{\mathbf{1}}\right)$

Non-Performing Financing of Mudaraba Financing is a calculation of financing by using a Mudaraba contract that is problematic with the category of traffic jam. This calculation is done by comparing Mudaraba financing which is stuck with the total amount of Mudaraba financing.

\section{Non-Performing Financing of Musharaka} Financing $\left(\mathbf{X}_{2}\right)$

Non-Performing Financing of Musharaka Financing is a calculation of financing by using Musharaka contracts that are problematic with the category of traffic jam. This calculation is done by comparing musharaka financing with stalled amount of musharaka financing as a whole.

\section{Profitability (Return On Asset) Y}

Profitability is the company's ability to earn profits from assets managed. Measurement of profitability in this study using Return on Assets (ROA) 


\section{Conceptual Framework}

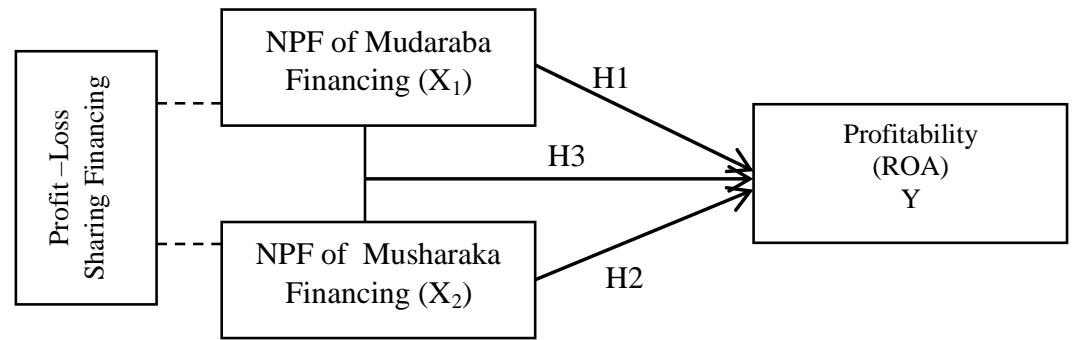

Figure 2. Conceptual Framework

Conceptual framework of this research describes the concept of research conducted. The concept of this study aims to analyze the effect of non-performing financing from the type of profit sharing for profitability of Islamic Commercial Bank in Indonesia. Nonperforming financing of the type of profit-loast sharing is measured using Non-Performing Financing of Mudaraba Financing $\left(\mathrm{X}_{1}\right)$ and Non Performing Financing of Musharaka Financing $\left(\mathrm{X}_{2}\right)$. While profitability is only measured by Return On Assets (ROA).

\section{ANALYSIS AND DISCUSSION}

\section{Research Result}

This research is conducted at Islamic Commercial Bank in Indonesia period 2014 until 2016. The data obtained from financial report of Islamic Commercial Bank in time series. Variable Non-Performing Financing of Mudaraba Financing $\left(\mathrm{X}_{1}\right)$ and Non-Performing Financing of Musharaka Financing $\left(\mathrm{X}_{2}\right)$. While profitability is only measured by Return On Assets (ROA). The variables in this study were measured using percentage calculations.

Table 1. Reseach Data

\begin{tabular}{lccccccccc}
\hline & \multicolumn{3}{c}{ 2014 (in \%) } & \multicolumn{3}{c}{ 2015 (in \%) } & \multicolumn{3}{c}{ 2016 (in \%) } \\
\cline { 2 - 9 } Month & ROA & NPF_Mud & NPF_Mush & ROA & NPF_Mud & NPF_Mush & ROA & NPF_Mud & NPF_Mush \\
\hline Januari & 0.08 & 4.09 & 1.41 & 0.88 & 3.55 & 6.27 & 1.01 & 2.34 & 5.99 \\
Februari & 0.13 & 4.83 & 1.64 & 0.78 & 4.09 & 6.60 & 0.81 & 2.69 & 5.89 \\
March & 1.16 & 4.41 & 1.47 & 0.69 & 3.44 & 5.79 & 0.88 & 2.52 & 5.44 \\
April & 1.09 & 4.75 & 1.53 & 0.62 & 3.30 & 5.40 & 0.80 & 2.40 & 5.42 \\
May & 1.13 & 5.50 & 1.65 & 0.63 & 3.16 & 5.44 & 0.16 & 2.85 & 5.60 \\
June & 1.12 & 5.27 & 1.73 & 0.50 & 2.68 & 5.29 & 0.73 & 1.95 & 5.22 \\
July & 0.69 & 3.23 & 5.52 & 0.50 & 2.58 & 5.21 & 0.63 & 2.09 & 4.76 \\
August & 0.55 & 4.65 & 6.09 & 0.46 & 2.51 & 5.31 & 0.48 & 2.45 & 4.99 \\
September & 0.53 & 3.98 & 6.84 & 0.49 & 2.50 & 5.21 & 0.59 & 2.32 & 4.66 \\
October & 0.56 & 4.23 & 6.19 & 0.51 & 2.47 & 5.12 & 0.46 & 2.33 & 4.55 \\
November & 0.49 & 4.04 & 6.73 & 0.52 & 2.39 & 4.98 & 0.67 & 2.92 & 4.56 \\
December & 0.41 & 3.61 & 5.77 & 0.49 & 2.18 & 5.09 & 0.63 & 2.62 & 3.66 \\
\hline
\end{tabular}

Source : Otoritas Jasa Keuangan (OJK)

Calculations in Table 1 are obtained by means of data processing that can produce processed data in accordance with the required in this study. Here is how the calculation processed data on each variable of this study.
NPF of Mudaraba Financing $\left(\mathrm{X}_{1}\right)=$ $\frac{\text { Number of NPF Mudaraba }}{\text { Number of Mudaraba Financing }}$ X 100\%

NPF of Musharaka Financing $\left(\mathrm{X}_{2}\right)=$ $\frac{\text { Number of NPF Musharaka }}{\text { Number of Musharaka Financing }}$ X 100\%.

Return On Asset (ROA) Y $=\frac{\text { Earning After Tax }}{\text { Total Assets }} \mathrm{X}$ 100 


\section{Hypothesis Test}

Table 2. Partial Test

Coefficients $^{\mathrm{a}}$

\begin{tabular}{|c|c|c|c|c|c|c|c|c|c|c|c|c|}
\hline \multirow[b]{2}{*}{ Model } & \multicolumn{2}{|c|}{$\begin{array}{l}\text { Unstandardized } \\
\text { Coefficients }\end{array}$} & \multirow{2}{*}{$\begin{array}{c}\begin{array}{c}\text { Standardized } \\
\text { Coefficients }\end{array} \\
\text { Beta }\end{array}$} & \multirow[b]{2}{*}{$\mathrm{T}$} & \multirow[b]{2}{*}{ Sig. } & \multicolumn{2}{|c|}{$\begin{array}{c}95,0 \% \text { Confidence } \\
\text { Interval for B } \\
\end{array}$} & \multicolumn{3}{|c|}{ Correlations } & \multicolumn{2}{|c|}{$\begin{array}{l}\text { Collinearity } \\
\text { Statistics }\end{array}$} \\
\hline & B & Std. Error & & & & $\begin{array}{l}\text { Lower } \\
\text { Bound }\end{array}$ & $\begin{array}{l}\text { Upper } \\
\text { Bound }\end{array}$ & $\begin{array}{l}\text { Zero- } \\
\text { order }\end{array}$ & Partial & Part & Tolerance & VIF \\
\hline 1 (Constant) & .535 & .272 & & 1.966 & .058 & -.019 & 1.089 & & & & & \\
\hline NPF_Mud & .054 & .051 & .204 & 1.075 & .290 & -.049 & .157 & .250 & .184 & .180 & .781 & 1.280 \\
\hline NPF_Mush & -.016 & .031 & -.098 & -.514 & .610 & -.079 & .047 & -.193 & -.089 & -.086 & .781 & 1.280 \\
\hline
\end{tabular}

a. Dependent Variable: ROA

Source : Data Process

Hypothesis 1: Non-Performing Financing (NPF) of Mudaraba Financing Influence to The Profitability of Islamic Commercial Bank

Based on table 2 obtained the calculation of the value of $t_{\text {count }}$ of 1.075 with a significance level of 0.290. $\mathrm{t}_{\text {table }}$ value obtained by 2,042 . The result shows that tc 1,075 $<$ ttabel 2.042 and significance level of 0.290> 0.05, thus Non-Performing Financing (NPF) of Mudaraba Financing has no significant effect on profitability of Islamic Commercial Bank. So the hypothesis that has been formulated that Non-Performing Financing (NPF) of Mudaraba Financing Influence to The Profitability Islamic Commercial Bank is rejected because it does not show any influence.

Hypothesis 2: Non-Performing Financing (NPF) of Musharaka Financing Influence to The Profitability of Islamic Commercial Bank

Table 3. Simultaneous Test of Hypothesis

\begin{tabular}{lllllll}
\hline \multicolumn{7}{c}{ MNOVA $^{\mathbf{b}}$} \\
\hline \multirow{2}{*}{1} & Sum of Squares & df & Mean Square & F & Sig. \\
\cline { 2 - 7 } & Regression & .168 & 2 & .084 & 1.240 & .303 $^{\text {a }}$ \\
\cline { 2 - 7 } & Residual & 2.230 & 33 & .068 & & \\
\cline { 2 - 6 } & Total & 2.398 & 35 & & \\
\hline
\end{tabular}

Based on Table 2 obtained the calculation of the value of $t_{\text {count }}$ of -0.514 with a significance level of $0.610 . \mathrm{t}_{\text {tabel }}$ value obtained 2,042. The result shows that $t_{\text {count }}-$ $0.514<\mathrm{t}_{\text {tabel }} 2.042$ and significance level of 0.610>0.05, thus Non Performing Financing (NPF) of Musharaka Financing has no significant effect on profitability of Islamic Commercial Bank. So the hypothesis that has been formulated that Non Performing Financing (NPF) of Musharaka Financing Influence to The Profitability Islamic Commercial Bank is rejected because it does not show any influence.

Hypothesis 3: Simultaneously NonPerforming Financing (NPF) of Mudaraba Financing and Non-Performing Financing (NPF) of Musharaka Financing Influence to The Profitability Of Islamic Commercial Bank. 
Based on table 3 obtained calculation of $F_{\text {count }}$ value of 1.240 with significance level of 0.303. based on the table obtained $\mathrm{F}_{\text {table }}$ value of 3300 at the level of significance 0.05 . It shows that the value of $\mathrm{F}_{\text {count }} 1.240<$ Ftabel 3.300 and the significance level of $0.303>$ 0.05 . It means that the results of hypothesis testing simultaneously show no significant effect. The hypothesis that Simultaneously Non-Performing Financing (NPF) of Mudaraba Financing and Non-Performing Financing (NPF) of Musharaka Financing Influence to The Profitability Islamic Commercial Bank was rejected.

Table 4. Coeficient Determinant Model Summary ${ }^{b}$

\begin{tabular}{|c|c|c|c|c|c|c|c|c|}
\hline \multirow[b]{2}{*}{ Model R } & \multirow[b]{2}{*}{$\begin{array}{c}\mathrm{R} \\
\text { Square }\end{array}$} & \multirow[b]{2}{*}{$\begin{array}{l}\text { Adjusted R } \\
\text { Square }\end{array}$} & \multirow[b]{2}{*}{$\begin{array}{l}\text { Std. Error of the } \\
\text { Estimate }\end{array}$} & \multicolumn{4}{|c|}{ Change Statistics } & \multirow[b]{2}{*}{$\begin{array}{l}\text { Durbin- } \\
\text { Watson }\end{array}$} \\
\hline & & & & $\begin{array}{l}\text { R Square } \\
\text { Change }\end{array}$ & $\begin{array}{c}\mathrm{F} \\
\text { Change }\end{array}$ & df1 df2 & $\begin{array}{l}\text { Sig. F } \\
\text { Change }\end{array}$ & \\
\hline $.264^{\mathrm{a}}$ & .070 & .014 & .25997 & .070 & 1.240 & 233 & .303 & 1.234 \\
\hline \multicolumn{9}{|c|}{ a. Predictors: (Constant), NPF_Mush, NPF_Mud } \\
\hline \multicolumn{4}{|c|}{ b. Dependent Variable: ROA } & & & & & \\
\hline
\end{tabular}

Based on table 4 shows the value of $R$ square of 0.070 with adjusted $\mathrm{R}$ square value of 0.14 . The results of this calculation indicate that the non-performing financing (NPF) variable of Mudaraba Financing and NonPerforming Financing (NPF) of Musharaka Financing does not simultaneously show strong, moderate, or low influence. $\mathrm{R}$ square value of 0.070 or $7 \%$ is a very low category, so it does not show any significant effect.

Overall, the results of this study indicate that problematic financing in Islamic banks does not affect the ability of Islamic commercial banks to earn profits. Results of multiple linear regression calculations obtained equation Profitability $=0.535+1.075 \mathrm{X}_{1}-$ $0.514 \mathrm{X}_{2}$.

\section{Discussion}

Non-Performing Financing (NPF) is a type of problem financing with the category of stalled or non-billable. This problematic financing will certainly affect the financial performance of Islamic banks. This study aims to examine the influence of Non-Performing Financing by Profit-Loss Sharing financing to the profitability of Islamic banks in Indonesia. Profit-Loss Sharing financing in Islamic Banking is explained by Mudaraba financing and Musharaka financing, since this nonperforming financing of profit sharing is measured by non performing financing of Mudaraba financing and non performing financing of Musharaka financing.

The results partially indicate that nonperforming financing of mudaraba financing and non-performing musharaka financing insignificant to the profitability of Islamic banks in Indonesia. This research is not in line with the results of previous research, where it showed a significant negative effect of non performing financing of mudharabah financing and non performing financing of musyarakah financing on the profitability of Islamic banks

Simultaneously showed that the two independent variables ie non performing 
Afkar, Influence Analysis of Non Performing Financing...

financing of Mudaraba financing and nonperforming financing of Musharaka financing does not significantly affect the profitability of Islamic banks in Indonesia. It reinforced by the value of determination coefficient of 0.070 or $7 \%$ only, meaning that there is no great influence and is classified as very low.

Profitability is the responsibility of the company's management. The profitability of Islamic banks in Indonesia in this study is not affected by problematic financing, thus Islamic banks are still able to obtain a large ratio of earnings from productive assets used primarily from mudaraba financing and musharaka financing. It fact still raises the question that the problematic financing should have a negative impact on the decrease in profits resulting from the receivables that can not be billed so that requires the treatment of writeoff of receivables.

These results indicate that the financing of profit-sharing through mudaraba and musharaka schemes has no effect on profitability. This scheme is actually a type of financing that is profit-sharing or includes types of financing that have not provided certainty of profit unlike types of financing based on receivables such as salam financing, ijara financing, murabaha financing, and istihna financing. Therefore, when there is a loss will be borne together between the lender and the borrower in accordance with the percentage, so as not to affect the ability of Islamic banks in obtaining profit.

Based on the financial statements of Islamic banks in Financial Services Authority (OJK), monthly report indicates that the type of financing that people are interested murabaha financing because it includes the type of financing more easily scheme and tend to fit the characteristics of the community with a consumptive lifestyle. While mudaraba financing and musharaka financing is a type of productive financing or real sector that prioritizes the business field undertaken. Maybe this is what causes problem financing from the type of profit sharing financing does not affect the profitability of Islamic banks in Indonesia.

\section{CONCLUSIONS}

\section{Conclusion}

1. Non Performing Financing of Mudaraba Financing does not significantly affect the profitability of Islamic banks in Indonesia. This result is shown by the partial calculation that $t_{\text {count }} 1,075<t_{\text {table }} 2.042$ and significance level of $0.290>0.05$. It shows that the problematic financing that occurs in Islamic banking during the period 2014 to 2016 does not affect the Islamic bank in terms of ability to earn a profit.

2. Non Performing Financing of Musharaka Financing does not significantly affect the profitability of Islamic banks in Indonesia. It is shown by partial calculation that $\mathrm{t}_{\text {count }}-0.514<\mathrm{t}_{\text {table }} 2.042$ and significance level of $0.610>0.05$. It results indicate that problematic financing in Islamic banking during the period 2014 to 2016 does not affect the ability of Islamic commercial banks to earn a profit. 
3. Simultaneously Non-Performing

Financing of Mudaraba Financing and Non-Performing Financing of Musharaka financing have no significant effect on profitability of Islamic commercial banks in Indonesia. It is shown by calculation simultaneously that the value of $\mathrm{F}_{\text {count }}$ $1,240<\mathrm{F}_{\text {table }} 3.300$ and significance level of $0.303>0.05$. It results indicate that non-performing financing of profit sharing does not affect the ability of Islamic commercial banks to earn profit during the period 2014 to 2016.

\section{Limitations}

1. Islamic Commercial Banks still pay attention to problematic financing with Mudaraba contract because this type of financing can be a problem when there are customers who intentionally do not pay the debt even though it has been able to pay, because the Mudaraba Financing identical with the financing entirely by the owner of the fund while the fund manager only conduct activities business and financial reporting.

2. Islamic Commercial Banks still pay attention to problematic financing with Musharaka Financing because this type of financing is identical with the cooperation model so that if there is a loss shared with both parties. Although the results of the study show no effect, there is nothing wrong to be careful in the distribution of financing.

3. Overall type of financing for the results does not affect the profitability of Islamic
Commercial Banks, but still need to note the type of problem financing on the contract for the results where this type of problematic financing if not managed properly will cause losses even to bankruptcy.

\section{REFERENCES}

Afkar, T. (2011). Strategi Pengembangan dan Sistem Bagi Hasil Perbankan Syariah di Indonesia. An Najah Jurnal Studi Islam, $1(1), 51-62$.

Afkar, T. (2014). Pengaruh Non Performing Finance Terhadap Likuiditas Perbankan Syariah di Indonesia (Studi Kasus Pasca Krisis Keuangan Global). Ekosiana:Jurnal Ekonomi Syariah, 1(2), 1-7.

Afkar, T. (2014). Pengaruh Pembiayaan Modal Kerja, Pembiayaan Investasi, dan Pembiayaan Konsumsi Terhadap Likuiditas Perbankan Syariah Indonesia (Studi Likuiditas Bank Umum Syariah dan Unnit Usaha Syariah. Cendekia., 8(1), 93-122.

Afkar, T. (2014). Pengaruh Risiko Kredit t Terhadap Kecukupan Modal Perbankan Syariah di Indonesia. Ekosiana:Jurnal Ekonomi Syariah, 2(2), 1-11.

Afkar, T. (2015a). Analisis Daya Tahan Perbankan Syariah Dalam Krisis Keuangan Global. Disertasi.

Afkar, T. (2015b). Financing mechanism of islamic banking. International Journal of Social Sciences, 32(1), 1-13.

Afkar, T. (2016). Efektivitas Pengendalian Preventif, Pengendalian Detektif, dan Pengendalian Represif Terhadap Pencegahan Kecurangan Akuntansi. Majalah Ekonomi, 21(2), 211-225.

Afkar, T. (2017a). Analisis Pengaruh Kredit Macet Dan Kecukupan Likuiditas Terhadap Efisiensi Biaya Operasional Bank Umum Syariah Di Indonesia. AJIE -Asian Journal of Innovation and Entrepreneurship, 2(2), 2477-2574.

Afkar, T. (2017b). Influence Analysis Of Mudharabah Financing And Qardh Financing To The Profitability Of Islamic Banking In Indonesia. AJIE - Asian Journal of Innovation and Entrepreneurship, 2(3), 340-351.

Copyright@2018 AKRUAL: Jurnal Akuntansi 
Afkar, T. (2017c). Pengaruh Pembiayaan Usaha Mikro, Kecil, Menengah (Umkm), Dan Kecukupan Modal Terhadap Kemampuan Mendapatkan Laba Dari Aset Perbankan Syariah Di Indonesia. Journal of Islamic Economics, 1(2), $2548-3544$.

Afkar, T. (2017d). Pengaruh Profitabilitas Terhadap Likuiditas Bank Umum Syariah di Indonesia. Seminar Nasional Hasil Penelitian Universitas Kanjuruhan Malang 2017, 1(1), 629-638.

Anjani, R., \& Hasmarani, M. I. (2015). Pengaruh Pembiayaan Mudharabah, Musyarakah dan Murabahah Terhadap Profitabilitas BPRS di Indonesia periode 2012-2015. Seminar Nasional Dan The 3rd Call for Syariah Paper, 175-183. DOI:https://doi.org/10.20885/jeki.vol2.is s2.art5

Bank Indonesia. (2007a). PBI No 9/9/PBI/2007 Tentang Perubahan Atas Peraturan Bank Indonesia Nomor 8/21/PBI/2006 Tentang Penilaian Kualitas Aktiva Bank Umum Yang Melaksanakan Kegiatan Usaha Berdasarkan Prinsip Syariah. PBI No 9/9/PBI/2007.

Bank Indonesia. (2007b). Surat Edaran No.9/24/DPbS Perihal: Sistem Penilaian Tingkat Kesehatan Bank Umum Berdasarkan Prinsip Syariah. SEBI 9/24/DPBs, 53(9), 1689-1699. https://doi.org/10.1017/CBO9781107415 324.004

Bank Indonesia. (2008). Surat Edaran Bank Indonesia No . 10 / 34 / DPbS tanggal 22 Oktober 2008 Perihal Restrukturisasi Pembiayaan Bagi Bank Umum Syariah dan Unit Usaha Syariah. SEBI 10/34/DPBs, (10), 1-3.

Bank Indonesia. 2009. Krisis Global dan Penyelamatan Sistem Perbankan Indonesia. Jakarta: Humas Bank Indonesia

Blanchflower, D. G. (1991). The Economic Effects of Profit Sharing in Great Britain. International Journal of Manpower, 12(1), 3-9. https://doi.org/10.1108/01437729110135 501
Diallo, O., Fitrijanti, T., \& Tanzil, N. D. (2015). Analysis of the influence of liquidity, credit and operational risk, in Indonesian islamic bank's financing for the period 2007-2013. Gadjah Mada International Journal of Business, 17(3), 279-294.

Fang, T. (2015). Profit sharing: Consequences for workers. IZA World of Labor. doi:10.15185/izawol.225

Hasyim, L. T. U. (2016). Peran Perbankan Syariah Terhadap Pertumbuhan Ekonomi Sektor Riil Di Indonesia. Akrual: Jurnal Akuntansi, 8(7), 11-27. http://dx.doi.org/10.26740/jaj.v8n1.p11-27

Judisseno, R.K. (2005). Sistem Moneter dan Perbankan di Indonesia. Jakarta: PT. Gramedia Pustaka Utama

Karim, A. A. (2010). Perbankan Islam Analisis Fiqih dan Keuangan. Jakarta: PT. Raja Grafindo Persada.

Laldin, M. A., \& Furqani, H. (2016). Innovation versus Replication: Some Notes on the Approaches in Defining Shariah Compliance in Islamic Finance. Al-Jami'ah: Journal of Islamic Studies, 54(2), 249. doi:10.14421/ajis.2016.542.249-272

Muhammad. (2008). Manajemen Pembiayaan Mudharabah di Bank Syariah (Strategi Memaksimalkan Return dan Meminimalkan Risiko Pembiayaan di Bank Syariah Sebagai Akibat Masalah Agency. Jakarta: PT. Raja Grafindo Persada.

Nurhayati, S., \& Wasilah. (2015). Akuntansi Syariah Di Indonesia. Jakarta : Selemba Empat.

Oktaviana, U. K. F. (2012). Financial Ratio to distinguish Islamic Banks, Islamic Business Units and Conventional Banks in Indonesia, Pertama. Jakarta: Kementrian Agama Republik Indonesia

Permata, R. I. D., Yaningwati, F., \& A, Z. Z. (2014). Analisis pengaruh pembiayaan mudharabah dan musyarakah terhadap tingkat profitabilitas ( return on equity) ( studi pada bank umum syariah yang terdaftar di bank indonesia periode 20092012 ). Jurnal Administrasi Bisnis, 12(1), $1-9$. 
Rivai, V., dkk. (2012). Banking and Finance (Dari Teori ke Praktik Bank dan Keuangan Syariah Sebagai Solusi dan Bukan Alternatif) Edisi Pertama. Yogyakarta: BPFE.

Saputra, A. W. (2013). Pengaruh Non Performing Finance (NPF) Pembiayaan Mudharabah dan Non Performing Finance (NPF) Pembiayaan Musyarakah Terhadap Profitabilitas Perbankan Syariah (Studi Kasus pada PT. Bank Syariah Mandiri Tahun 1999-2013). Syariah Paper Accounting. FEB UMS, ISSN 2460-0784, (10).

Satriawan, A., \& Arifin, Z. (2016). Analisis Profitabilitas Dari Pembiayaan Mudharabah, Musyarakah, Dan Murabahah Pada Bank Umum Syariah Di Indonesia Periode 2005-2010. Media Riset Akuntansi, Auditing Dan Informasi, 12(1), 1. doi:10.25105/mraai.v12i1.580

Sutojo, S. (2008). Seri Manajemen Perbankan No.6 - Strategi Manajemen Kredit Perbankan Umum : Konsep, Teknik dan Kasus. Jakarta : Damar Mulia Pustaka.

Beck, T., Demirgüç-Kunt, A., \& Merrouche, O. (2013). Islamic vs. conventional banking: Business model, efficiency and stability. Journal of Banking \& Finance, 37(2), 433-447.

doi:10.1016/j.jbankfin.2012.09.016

Uman, C., \& Afkar, T. (2011). Modul Kewirausahaan Untuk Mahasiswa dan Umum. Surabaya: IAIN Sunan Ampel Press

Ushanti, T.P., \& Shomad. (2013). Transaksi Bank Syariah. Jakarta. Bumi Aksara

Wibowo, A., \& Sunarto. (2014). Pengaruh Pembiayaan Mudharabah Dan Musyarakah Terhadap Profitabilitas Perbankan Syariah (Studi Kasus Pada Bank Pembiayaan Rakyat Syariah Daerah Istimewa Yogyakarta Yang Terdaftar Di Bank Indonesia Periode 2012-2014). Seminar Nasional Dan The 3rd Call for Syariah Paper, 115-124. 